\title{
High Efficiency of Propagation for Sagittaria sagittifolia Using a Temporary Immersion Bioreactor System
}

\author{
Meiping Gao ${ }^{1}$, Zhicheng $\operatorname{Lin}^{1}$, Cong $\mathrm{Luo}^{2}$, Zhang $\mathrm{Chi}^{3}$, Zhihuan $\mathrm{Mo}^{3}$, Fanglian $\mathrm{He}^{1}$, Wen Jiang ${ }^{1}$, Lijuan $\mathrm{Chen}^{1}$, \\ Xinhua $\mathrm{He}^{2}$ and Shaolong $\mathrm{Wei}^{1}$ \\ 1. Biotechnology Research Institute, Guangxi Academy of Agricultural Sciences, No. 174, Daxue Road, Nanning, Guangxi 530007, \\ China \\ 2. College of Agriculture, Guangxi University, No. 100, Daxue Road, Nanning, Guangxi 530007, China \\ 3. Agricultural Bureau in Ping Le Areas, Guangxi 542400, China
}

\begin{abstract}
Although several studies have reported on the propagation of the Sagittaria sagittifolia to date, none of these methods have efficiently achieved the mass production of these plants. The present study aimed to investigate the propagation and growth of $S$. sagittifolia using a temporary immersion bioreactor system (TIBS) compared with conventional semi-solid and liquid culture. The effect of different immersion frequencies and immersion times together with supplementation of various plant growth regulators to the Murashige and Skoog (MS) medium was evaluated on shoot proliferation and plant growth. The results showed that the higher immersion frequency (every $6 \mathrm{~h}$ ) and shorter immersion time (3 min and $10 \mathrm{~min}$ ) in medium containing $4 \mathrm{mg} / \mathrm{L} \mathrm{BA}$ and $0.1 \mathrm{mg} / \mathrm{L}$ NAA produced the highest multiplication rate (23), which are significantly higher than conventional semi-solid (3.6) and liquid (4.5) method, and the best plant growth parameter. While, the lower immersion frequency and longer immersion time (30 min every $12 \mathrm{~h}$ and $60 \mathrm{~min}$ every $24 \mathrm{~h}$ ) induced vitrification and pollution rate in shoot tips $16.6 \%$ and $19 \%, 42 \%$ and $37 \%$, respectively. There is distinct decrease in pollution rate $(8.3 \%)$ in TIBS (10 min every $6 \mathrm{~h})$ compared with the conventional semi-solid and liquid cultures. Medium containing $4 \mathrm{mg} / \mathrm{L} \mathrm{BA}$ and $0.5 \mathrm{mg} / \mathrm{L}$ NAA using $10 \mathrm{~min}$ immersion every $6 \mathrm{~h}$ showed satisfaction at the rooting stage, with high shoot proliferation rate (21.6), 100\% rooting and 94\% plant survival. Therefore, applying TIBS in S. sagittifolia is an efficient method for scaling up the production of plantlets with high quality seedlings.
\end{abstract}

Key words: Sagittaria sagittifolia, temporary immersion bioreactor system, proliferation and growth, root formation.

\section{Introduction}

Sagittaria sagittifolia is an aquatic plant belonging to the family Alismaceae. It mainly distributes in water areas of the Southern China, Japan and India. Sagittaria is favorite by people for the value both in food and medicine, as one of main off-season aquatic vegetables during winter and spring [1]. The propagation plantlets are increasingly used for the commercial cultivation of Sagittaria, because the plant material is clean and easy to manipulate and enables the synchronized harvest. Several studies have been conducted on the propagation of $S$. sagittifolia by semi-solid and liquid culture. However, the existing

Corresponding author: Shaolong Wei, professor, research fields: plant tissue culture research and breeding new varieties. propagation techniques that use Sagittaria meristem and shoot tips as explants are labor-intensive and require large laboratory space $[2,3]$. The superiority of liquid culture system in proliferation processes seems to be an ideal solution of the cost and labor requirements, and more enable to automation [4-6], but their uses are often limited for the incidence of hyperhydricity and severe physiological disorders in plantlets [7, 8]. It was found that in the process of $S$. sagittifolia regeneration both in semi-solid and liquid medium, shoot pollution is severe $[9,10]$. To overcome these drawbacks, new studies on efficient method for S. sagittifolia in vitro mass propagation are needed to be developed. Various strategies have been applied for the scale-up of propagation systems based either on organogenesis or on embryogenesis in liquid 
medium using temporary immersion bioreactors of the explants. Several studies have used different bioreactors, such as bubble bioreactors, continuous and dis-continuous gassing bioreactors, and temporary immersion bioreactor system (TIBS) or the RITA $^{\circledR}$ bioreactor system on the shoot and embryo proliferation [11]. A temporary immersion bioreactor has been successfully used in the propagation of Sagittaria with different frequencies of immersion. The objective of this study was to establish a TIBS protocol for the propagation of Sagittaria, and then compare it with the conventional semi-solid and liquid culture. The effect of immersion frequency together with supplementation of various plant growth regulators to the medium was evaluated on shoot proliferation and plant growth.

\section{Materials and Methods}

\subsection{Plant Materials and Culture Condition}

An in vitro S. sagittifolia plant was obtained by sterile sucker tips offered by Guangxi Plant Tissue Culture Company Limited (LTD). Shoot tips were surface sterilized with ethanol $(70 \% \mathrm{w} / \mathrm{v})$ for $20 \mathrm{~s}$, followed by $12 \mathrm{~min}$ in $0.1 \%$ (w/v) mercuric chloride, and then by three times rinsed with sterile distilled water. Then, they were inoculated into individual bottles containing $35 \mathrm{~mL}$ of basal Murashige and Skoog (MS) medium [12] supplemented with $2 \mathrm{mg} / \mathrm{L}$ BA, $0.1 \mathrm{mg} / \mathrm{L}$ NAA, $30 \mathrm{~g} / \mathrm{L}$ sucrose and $3.1 \mathrm{~g} / \mathrm{L}$ agar. After four weeks, shoot tips were transferred to a TIBS described by Nimenak et al. [13] (Fig. 1). The shoots were inoculated into a $3 \mathrm{~L}$ glass bottle (diameter $15 \mathrm{~cm}$, height $25 \mathrm{~cm}$ ) containing $1 \mathrm{~L}$ of proliferation medium, which was sealed with rubber plugs. The medium was moved periodically by using compressed air, which was sterilized through a $0.2 \mu \mathrm{m}$ air filter. Magnetic valves were applied an on/off operation while timers controlled the light, frequency and duration of immersion period. All cultures regardless of whether on semi-solid, liquid medium or TIBS were maintained at $26 \pm 2{ }^{\circ} \mathrm{C}$ under a $16 \mathrm{~h}$ light $/ 8 \mathrm{~h}$ dark photoperiod under cool white light $(60$ $\left.\mu \mathrm{mol} / \mathrm{m}^{2} \cdot \mathrm{s}\right)$.

\subsection{Optimization of High Efficiency Proliferation on S.} sagittifolia

To determine the optimum immersion frequency, $S$. sagittifolia shoots were transferred to TIBS containers and the system was controlled by a timer set at $3 \mathrm{~min}$ immersion every $4,6,8,12$ or $24 \mathrm{~h}$.

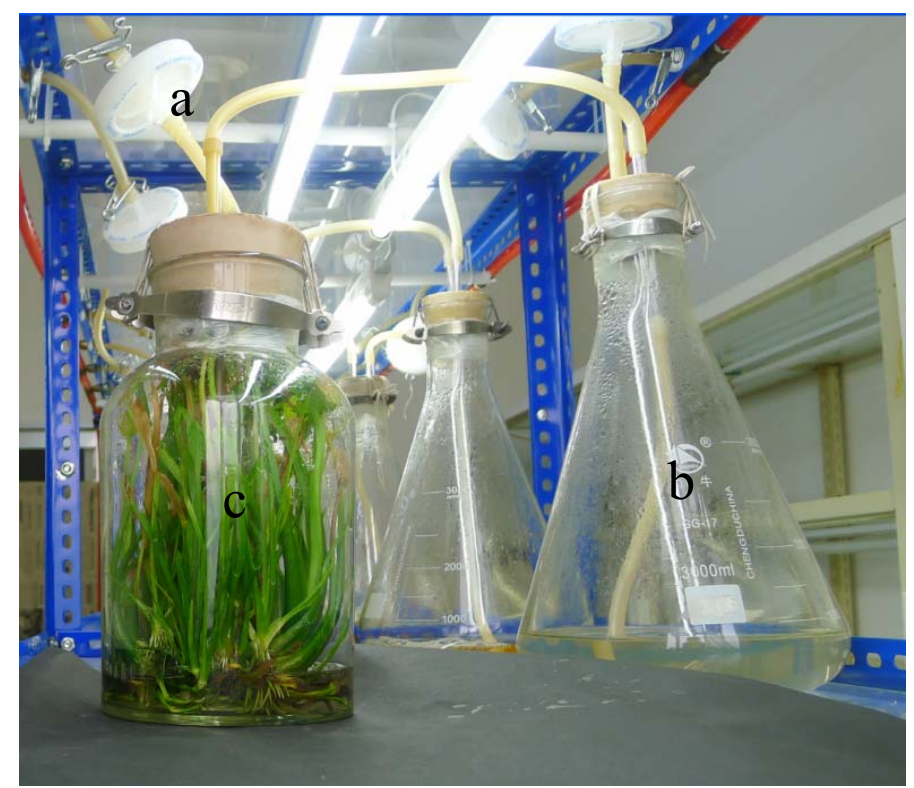

Fig. 1 The schematic diagram of TIBS.

a: $22 \mathrm{~m}$ air filter; b: liquid storage flasks; c: culture bottles. 
Following the determination of an optimum immersion frequency, the different immersion times set at 1, 3, 10,30 or 60 min every $6 \mathrm{~h}$ were used to test the proliferation and growth of S. sagittifolia shoots.

The effect of different combinations of MS medium containing BA $(4 \mathrm{mg} / \mathrm{L}$ or $2 \mathrm{mg} / \mathrm{L})$ with NAA $(0.1$ $\mathrm{mg} / \mathrm{L}$ or $0.5 \mathrm{mg} / \mathrm{L}$ ) was tested on the proliferation and growth of $S$. sagittifoliain shoots in semi-sold medium, liquid medium and TIBS. As an optimized condition, the TIBS was set at $10 \mathrm{~min}$ immersion time every $6 \mathrm{~h}$.

To evaluate the effect of different conditions on pollution and vitrification of $S$. sagittifoliain, different immersion frequencies ( 3 min immersion every 4, 6, 8, 12 or $24 \mathrm{~h})$ and immersion times $(1,3,10,30$, or 60 min) were examined after five weeks in TIBS.

To evaluate the effect of rooting and acclimatization on $S$. sagittifoliain, in vitro shoots of $S$. sagittifolia grown for four weeks on the basal MS medium were transferred to semi-solid medium, liquid medium and TIBS. Each MS medium containing 4 $\mathrm{mg} / \mathrm{L} \mathrm{BA}$ and $0.5 \mathrm{mg} / \mathrm{L}$ NAA, and TIBS with $10 \mathrm{~min}$ immersion every $6 \mathrm{~h}$ were used for rooting. The tissue was cultured for six weeks on rooting medium. Then, the plantlets were subjected to a $10 \mathrm{~d}$ acclimatization period and transferred to a greenhouse. After 1 month, the number of survived plantlets was scored.

\subsection{Statistical Analysis}

Each experiment was repeated at least twice, following six weeks of the proliferation phase, and the growth parameters (number of leaves per shoot, shoot length, stem diameter, number of roots per shoot, root length and rooting) were measured. Moreover, the pollution and vitrification of $S$. sagittifolia were also measured after five weeks in the proliferation phase. The significance of differences was determined by analysis of the variance (ANOVA) and the means were separated by Sudent-Newman-Keuls (SNK) $(P<$ $0.05)$ multiple-range test.

\section{Results}

\subsection{Effect of Different Immersion Frequencies on} Shoot Proliferation and Growth of S. sagittifolia after Six Weeks in TIBS

Immersion frequency is considered to be an important parameter for the efficiency of TIBS. It also has an effect on the multiplication rate (Table 1). As shown in Table 1, as the extension of immersion frequency from $4 \mathrm{~h}$ to $24 \mathrm{~h}$, the number of leaves and roots, and root length per explant increased. Immersion in 3 min every $24 \mathrm{~h}$ resulted in the maximum number of leaves and roots, stem diameter, and root length per explants $(9.1,41.3,1.4 \mathrm{~cm}, 4.0 \mathrm{~cm}$, respectively). Moreover, immersion frequency between $4 \mathrm{~h}$ and $6 \mathrm{~h}$ or $12 \mathrm{~h}$ and $24 \mathrm{~h}$, shoot proliferation and growth showed significant differences. There were no observed differences in the number of leaves and roots, stem diameter, root length and also shoot length. In the case of $6 \mathrm{~h}$ and $8 \mathrm{~h}$ immersion frequency, proliferation showed no significant differences between $8 \mathrm{~h}$ and $12 \mathrm{~h}$ immersion frequency. A significantly higher multiplication rate (20 times) was obtained using $3 \mathrm{~min}$ immersion every $6 \mathrm{~h}$.

Table 1 Effect of different immersion frequencies on shoot proliferation and growth of S. sagittifolia after six weeks in TIBS.

\begin{tabular}{lllllllll}
\hline \multirow{2}{*}{$\begin{array}{l}\text { Immersion } \\
\text { frequency }\end{array}$} & $\begin{array}{l}\text { Number of leaves } \\
\text { per explant }\end{array}$ & $\begin{array}{l}\text { Shoot length } \\
(\mathrm{cm})\end{array}$ & $\begin{array}{l}\text { Stem diameter Proliferation } \\
(\mathrm{cm})\end{array}$ & $\begin{array}{l}\text { Root } \\
\text { times }\end{array}$ & $\begin{array}{l}\text { Number of root } \\
\text { per explant }\end{array}$ & $\begin{array}{l}\text { Root length } \\
(\mathrm{cm})\end{array}$ & $\begin{array}{l}\text { Rooting } \\
(\%)\end{array}$ \\
\hline 3 min every 4 h & $4.3^{\mathrm{d}}$ & $12.3^{\mathrm{c}}$ & $0.63^{\mathrm{d}}$ & $16.3^{\mathrm{b}}$ & $18.6^{\mathrm{d}}$ & $1.5^{\mathrm{d}}$ & $84.0^{\mathrm{b}}$ \\
3 min every 6 $\mathrm{h}$ & $6.2^{\mathrm{c}}$ & $15.3^{\mathrm{b}}$ & $0.78^{\mathrm{c}}$ & $20.0^{\mathrm{a}}$ & $21.4^{\mathrm{c}}$ & $2.6^{\mathrm{c}}$ & $100.0^{\mathrm{a}}$ \\
3 min every 8 h & $6.5^{\mathrm{c}}$ & $17.2^{\mathrm{a}}$ & $0.85^{\mathrm{c}}$ & $16.2^{\mathrm{b}}$ & $25.5^{\mathrm{c}}$ & $2.7^{\mathrm{c}}$ & $100.0^{\mathrm{a}}$ \\
3 min every 12 h $7.3^{\mathrm{b}}$ & $19.0^{\mathrm{a}}$ & $1.1^{\mathrm{b}}$ & $15.2^{\mathrm{b}}$ & $31.1^{\mathrm{b}}$ & $3.1^{\mathrm{b}}$ & $100.0^{\mathrm{a}}$ \\
3 min every 24 h 9.1 & $14.7^{\mathrm{b}}$ & $1.4^{\mathrm{a}}$ & $12.7^{\mathrm{c}}$ & $41.3^{\mathrm{a}}$ & $4.0^{\mathrm{a}}$ & $100.0^{\mathrm{a}}$ \\
\hline
\end{tabular}

${ }^{\mathrm{a}-\mathrm{d}}$ Different letters indicate significant differences $(P<0.05)$ according to the post-hoc multiple comparisons test. 
Table 2 Effect of different immersion times on shoot proliferation and growth of $S$. sagittifolia after six weeks in TIBS.

\begin{tabular}{|c|c|c|c|c|c|c|c|}
\hline \multirow{2}{*}{$\begin{array}{l}\text { Immersion } \\
\text { time }\end{array}$} & \multicolumn{4}{|c|}{ Shoot } & \multicolumn{3}{|c|}{ Root } \\
\hline & $\begin{array}{l}\text { Number of leaves } \\
\text { per explant }\end{array}$ & $\begin{array}{l}\text { Shoot length } \\
(\mathrm{cm})\end{array}$ & $\begin{array}{l}\text { Stem diameter } \\
(\mathrm{cm})\end{array}$ & $\begin{array}{l}\text { Proliferation } \\
\text { times }\end{array}$ & $\begin{array}{l}\text { Number of root } \\
\text { per explant }\end{array}$ & $\begin{array}{l}\text { Root length } \\
(\mathrm{cm})\end{array}$ & $\begin{array}{l}\text { Rooting } \\
(\%)\end{array}$ \\
\hline 1 min every $6 \mathrm{~h}$ & $4.6^{\mathrm{e}}$ & $13.2^{\mathrm{d}}$ & $0.8^{\mathrm{d}}$ & $11.7^{\mathrm{e}}$ & $23.4^{\mathrm{c}}$ & $2.0^{\mathrm{d}}$ & $72.0^{\mathrm{c}}$ \\
\hline 3 min every $6 h$ & $6.8^{\mathrm{d}}$ & $16.0^{\mathrm{c}}$ & $1.3^{\mathrm{c}}$ & $19.8^{\mathrm{b}}$ & $25.1^{\mathrm{c}}$ & $2.7^{\mathrm{c}}$ & $89.0^{\mathrm{b}}$ \\
\hline 10 min every $6 \mathrm{~h}$ & $7.1^{\mathrm{c}}$ & $19.2^{\mathrm{b}}$ & $2.0^{\mathrm{b}}$ & $21.0^{\mathrm{a}}$ & $33.5^{\mathrm{b}}$ & $3.1^{\mathrm{b}}$ & $100.0^{\mathrm{a}}$ \\
\hline 30 min every $6 \mathrm{~h}$ & $9.0^{\mathrm{a}}$ & $20.4^{\mathrm{a}}$ & $2.6^{\mathrm{a}}$ & $18.0^{\mathrm{c}}$ & $41.2^{\mathrm{a}}$ & $4.2^{\mathrm{a}}$ & $100.0^{\mathrm{a}}$ \\
\hline 60 min every $6 \mathrm{~h}$ & $8.1^{\mathrm{b}}$ & $17.0^{\mathrm{c}}$ & $2.0^{\mathrm{b}}$ & $13.5^{\mathrm{d}}$ & $34.7^{\mathrm{b}}$ & $3.5^{\mathrm{b}}$ & $100.0^{\mathrm{a}}$ \\
\hline
\end{tabular}

${ }^{\mathrm{a}-\mathrm{e}}$ Different letters indicate significant differences $(P<0.05)$ according to the post-hoc multiple comparisons test.

\subsection{Effect of Different Immersion Times on Shoot} Proliferation and Growth of S. sagittifolia after Six Weeks in TIBS

As shown in Table 2, prolonging the immersion time from $1 \mathrm{~min}$ to $60 \mathrm{~min}$, except shoot proliferation, the number of leaves and roots, shoot and root length, stem diameter increased rapidly and then decreased. The best multiplication rate (21 times) was obtained with immersion $10 \mathrm{~min}$ every $6 \mathrm{~h}$. These growth parameters came to the maximum $(9.0,41.2,20.4 \mathrm{~cm}$, $4.2 \mathrm{~cm}, 2.6 \mathrm{~cm}$, respectively, for number of leaves per explant, number of root per explants, shoot length, root length, stem diameter). When the immersion times up to $60 \mathrm{~min}$, these growth parameters decreased rapidly in the following from 9.0 to 8.1, 41.2 to $34.7,20.4 \mathrm{~cm}$ to $17.0 \mathrm{~cm}, 4.2 \mathrm{~cm}$ to $3.5 \mathrm{~cm}$, $2.6 \mathrm{~cm}$ to $2.0 \mathrm{~cm}$, respectively. There were significant differences in number of leaves and shoot proliferation at different immersion times, but no significant differences were observed in stem diameter, root numbers and root length at immersion $10 \mathrm{~min}$ and $60 \mathrm{~min}$ every $6 \mathrm{~h}$. Furthermore, there were no differences detected in the number of roots and shoot length between immersion $3 \mathrm{~min}$ and $1 \mathrm{~min}$ or $3 \mathrm{~min}$ and $60 \mathrm{~min}$ every $6 \mathrm{~h}$. All the above, the optimal system is with $10 \mathrm{~min}$ immersions every $6 \mathrm{~h}$ for the proliferation and growth of $S$. sagittifolia.

\subsection{Effect of Different Plant Growth Regulators on} Shoot Proliferation and Growth of S. sagittifolia after Six Weeks in Semi-sold Medium, Liquid Medium and TIBS

To determine the optimal plant growth regulators, the different BA and NAA concentrations containing in the semi-sold culture, liquid culture and TIBS were tested using $10 \mathrm{~min}$ immersion every $6 \mathrm{~h}$. As shown in Table 3, plantlets treat with $4 \mathrm{mg} / \mathrm{L}$ and $2 \mathrm{mg} / \mathrm{L} \mathrm{BA}$ concentrations displayed significant differences in the number of leaves and shoot length in these three culture methods.

On the contrast, no significant differences were observed in stem diameter, number of leaves, root length between semi-sold medium and liquid medium, but in TIBS, there were significant differences in stem diameter, number of roots and root length. Furthermore, significant differences in stem diameter, number of roots and root length were observed in three culture methods. When NAA concentration was $0.5 \mathrm{mg} / \mathrm{L}$ and $0.1 \mathrm{mg} / \mathrm{L}$, the results showed significant difference in number of leaves in semi-sold culture and liquid culture, while no significant difference was observed in TIBS. By conventional semi-solid and liquid methods, the higher BA concentrations were better in shoot proliferation, but no effect on root length. The higher NAA concentrations were better in plantlet growth parameters, except shoot proliferation. On the contrast, in TIBS, BA and NAA concentrations showed marked differences in plantlet growth parameters and shoot proliferation, except NAA concentration had no significant effect on the number of leaves. The efficiency of TIBS was significantly better than that of conventional method on M1, M2, M3 or M4 (Fig. 2). Among them, M2 medium (4 mg/L BA + $0.1 \mathrm{mg} / \mathrm{L} \mathrm{NAA}$ ) was the optimum as for the best shoot proliferation (23 times), and M3 showed the best in growth parameters (Fig. 2b). 
a Temporary Immersion Bioreactor System

Table 3 Effect of different plant growth regulators on shoot proliferation and growth.

\begin{tabular}{|c|c|c|c|c|c|c|c|}
\hline \multirow[b]{2}{*}{ Medium } & \multirow[b]{2}{*}{ PGRs } & \multicolumn{4}{|c|}{ Shoot } & \multicolumn{2}{|l|}{ Root } \\
\hline & & $\begin{array}{l}\text { No. of leaves } \\
\text { per explant }\end{array}$ & $\begin{array}{l}\text { Shoot length } \\
(\mathrm{cm})\end{array}$ & $\begin{array}{l}\text { Stem diameter } \\
(\mathrm{cm})\end{array}$ & $\begin{array}{l}\text { Proliferation } \\
\text { times }\end{array}$ & $\begin{array}{l}\text { No. of root } \\
\text { per explant }\end{array}$ & $\begin{array}{l}\text { Root length } \\
(\mathrm{cm})\end{array}$ \\
\hline \multicolumn{8}{|c|}{ Semi-solid } \\
\hline M1 & $2 \mathrm{mg} / \mathrm{L} \mathrm{BA}+0.1 \mathrm{mg} / \mathrm{L} \mathrm{NAA}$ & $5.10^{\mathrm{f}}$ & $6.40^{\mathrm{g}}$ & $0.50^{\mathrm{fg}}$ & $2.00^{\mathrm{g}}$ & $18.70^{\mathrm{f}}$ & $0.92^{\mathrm{g}}$ \\
\hline M2 & $4 \mathrm{mg} / \mathrm{L} \mathrm{BA}+0.1 \mathrm{mg} / \mathrm{L} \mathrm{NAA}$ & $7.30^{\mathrm{d}}$ & $5.60^{\mathrm{h}}$ & $0.45^{\mathrm{gh}}$ & $3.60^{\mathrm{ef}}$ & $16.10^{\mathrm{g}}$ & $0.84^{\mathrm{g}}$ \\
\hline M3 & $2 \mathrm{mg} / \mathrm{L} \mathrm{BA}+0.5 \mathrm{mg} / \mathrm{L} \mathrm{NAA}$ & $6.40^{\mathrm{e}}$ & $8.30^{\mathrm{e}}$ & $0.70^{\mathrm{e}}$ & $2.10^{\mathrm{g}}$ & $24.30^{\mathrm{e}}$ & $1.50^{\mathrm{f}}$ \\
\hline M4 & $4 \mathrm{mg} / \mathrm{L} \mathrm{BA}+0.5 \mathrm{mg} / \mathrm{L} \mathrm{NAA}$ & $8.30^{\mathrm{ab}}$ & $7.60^{f}$ & $0.60^{\mathrm{fg}}$ & $3.30^{\mathrm{ef}}$ & $20.00^{\mathrm{f}}$ & $1.40^{\mathrm{f}}$ \\
\hline \multicolumn{8}{|l|}{ Liquid } \\
\hline M1 & $2 \mathrm{mg} / \mathrm{L} \mathrm{BA}+0.1 \mathrm{mg} / \mathrm{L} \mathrm{NAA}$ & $5.70^{\mathrm{f}}$ & $6.80^{\mathrm{g}}$ & $0.42^{\text {gh }}$ & $3.60^{\mathrm{ef}}$ & $22.10^{\mathrm{e}}$ & $2.00^{\mathrm{e}}$ \\
\hline M2 & $4 \mathrm{mg} / \mathrm{L} \mathrm{BA}+0.1 \mathrm{mg} / \mathrm{L} \mathrm{NAA}$ & $6.70^{\mathrm{cd}}$ & $6.10^{\mathrm{h}}$ & $0.35^{\mathrm{h}}$ & $4.50^{\mathrm{e}}$ & $18.60^{\mathrm{f}}$ & $2.00^{\mathrm{e}}$ \\
\hline M3 & $2 \mathrm{mg} / \mathrm{L} \mathrm{BA}+0.5 \mathrm{mg} / \mathrm{L} \mathrm{NAA}$ & $6.30^{\mathrm{e}}$ & $8.20^{\mathrm{e}}$ & $0.64^{\mathrm{ef}}$ & $3.60^{\mathrm{ef}}$ & $31.70^{\mathrm{c}}$ & $2.70^{\mathrm{d}}$ \\
\hline M4 & $4 \mathrm{mg} / \mathrm{L} \mathrm{BA}+0.5 \mathrm{mg} / \mathrm{L} \mathrm{NAA}$ & $7.70^{\text {bcd }}$ & $7.40^{\mathrm{fg}}$ & $0.50^{\mathrm{fg}}$ & $4.10^{\mathrm{e}}$ & $28.50^{\mathrm{d}}$ & $2.60^{\mathrm{d}}$ \\
\hline \multicolumn{8}{|l|}{ TIBS } \\
\hline M1 & $2 \mathrm{mg} / \mathrm{L} \mathrm{BA}+0.1 \mathrm{mg} / \mathrm{L} \mathrm{NAA}$ & $5.20^{\mathrm{f}}$ & $18.70^{\mathrm{c}}$ & $1.80^{\mathrm{b}}$ & $16.10^{\mathrm{c}}$ & $42.00^{\mathrm{b}}$ & $3.20^{\mathrm{c}}$ \\
\hline M2 & $4 \mathrm{mg} / \mathrm{L} \mathrm{BA}+0.1 \mathrm{mg} / \mathrm{L} \mathrm{NAA}$ & $8.20^{\mathrm{abc}}$ & $17.70^{\mathrm{d}}$ & $1.20^{\mathrm{d}}$ & $23.00^{\mathrm{a}}$ & $28.70^{\mathrm{d}}$ & $2.80^{\mathrm{d}}$ \\
\hline M3 & $2 \mathrm{mg} / \mathrm{L} \mathrm{BA}+0.5 \mathrm{mg} / \mathrm{L} \mathrm{NAA}$ & $5.40^{\mathrm{f}}$ & $22.90^{\mathrm{a}}$ & $2.20^{\mathrm{a}}$ & $14.40^{\mathrm{d}}$ & $52.30^{\mathrm{a}}$ & $4.50^{\mathrm{a}}$ \\
\hline M4 & $4 \mathrm{mg} / \mathrm{L} \mathrm{BA}+0.5 \mathrm{mg} / \mathrm{L} \mathrm{NAA}$ & $8.50^{\mathrm{a}}$ & $21.70^{\mathrm{b}}$ & $1.40^{\mathrm{c}}$ & $21.60^{\mathrm{b}}$ & $34.80^{\mathrm{c}}$ & $3.80^{\mathrm{b}}$ \\
\hline
\end{tabular}

PGRs: plant growth regulators.

${ }^{\mathrm{a}-\mathrm{h}}$ Different letters indicate significant differences $(P<0.05)$ according to the post-hoc multiple comparisons test.

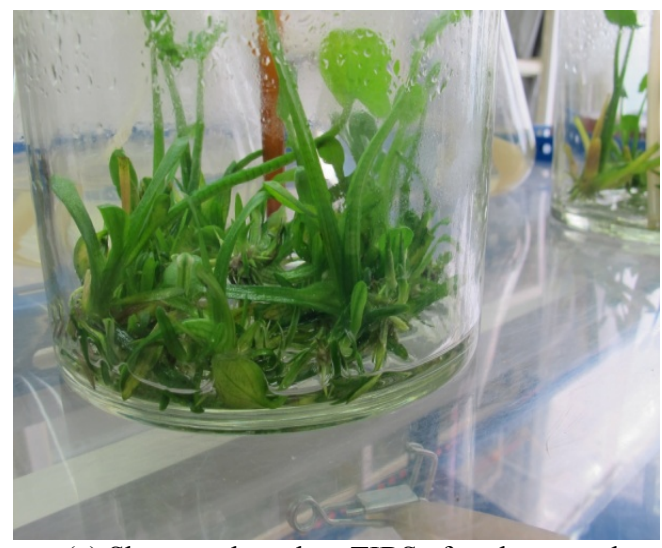

(a) Shoots cultured on TIBS after three weeks

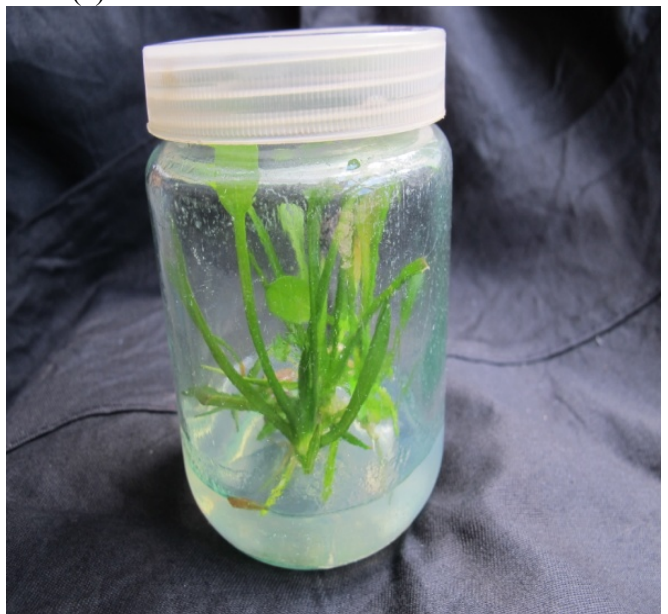

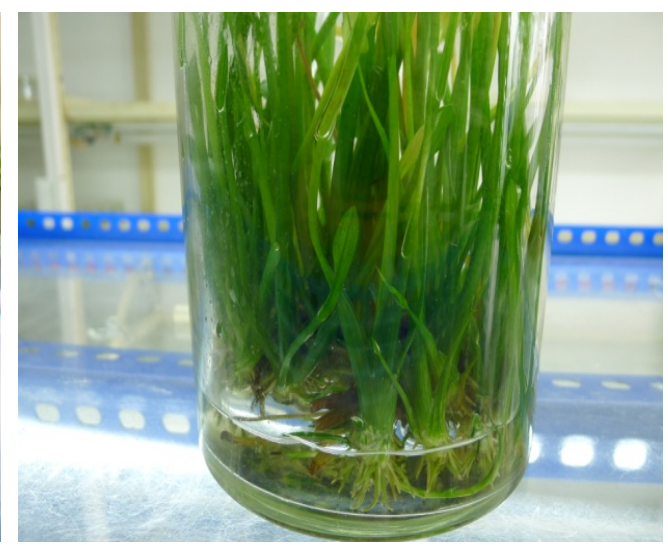

(b) Shoots cultured on TIBS after six weeks

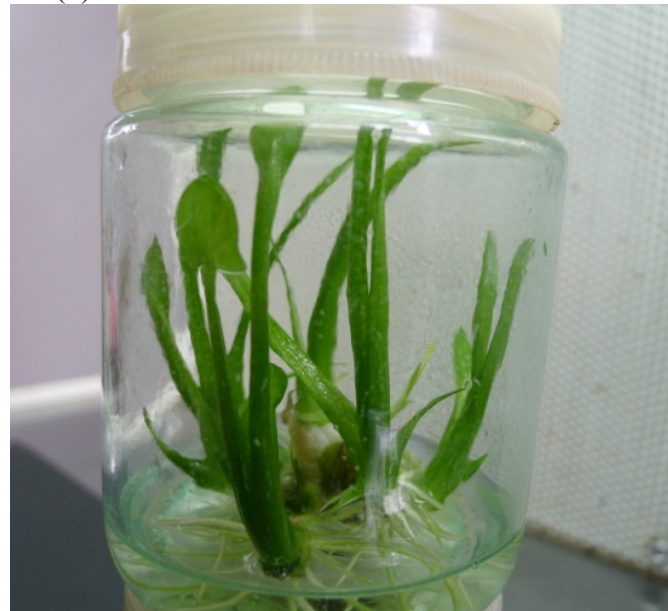

(c) Shoots cultured on semi-solid medium after four weeks (d) Shoots cultured on liquid medium after four weeks

Fig. 2 Effect of three culture methods on S. sagittifolia proliferation and growth. 
Vitrification was observed in conventional semi-solid and liquid medium, when the BA concentration reached $4 \mathrm{mg} / \mathrm{L}$ (M2, M4 medium). However, vitrification did not occur in TIBS using $10 \mathrm{~min}$ immersion every $6 \mathrm{~h}$, regardless of plant growth regulators concentrations.

\subsection{The Pollution and Vitrification of S. sagittifolia in TIBS}

Different immersion frequencies ( $3 \mathrm{~min}$ immersion every $4,6,8,12$ or $24 \mathrm{~h}$ ) on pollution and vitrification rate were tested after five weeks in TIBS. Plantlet pollution and vitrification rates were affected by immersion frequency (Fig. 3a). As prolonging the immersion frequency from $4 \mathrm{~h}$ to $8 \mathrm{~h}$, vitrification rate was not significantly effected, and also no significant difference between $6 \mathrm{~h}$ and $8 \mathrm{~h}$ in pollution percentage. and then it increased rapidly from $3 \%$ to $25 \%$ for $S$. sagittifolia immersion $3 \mathrm{~min}$ from every $8 \mathrm{~h}$ to $24 \mathrm{~h}$ after five weeks in TIBS. Immersion 3 min every $24 \mathrm{~h}$, pollution and vitrification rates came to the maximum (42\% and 25\%, respectively) (Fig. 3a), and furthermore the plant's green faded gradually. In the case of immersion times (1, 3, 10, 30 or $60 \mathrm{~min})$, pollution and vitrification rate remained stable from 1 min to $10 \mathrm{~min}$ immersion time, but as extended immersion time from $10 \mathrm{~min}$ to $60 \mathrm{~min}$, the percentage increased rapidly from $8.3 \%$ to $33 \%$ and $1 \%$ to $37 \%$, respectively. Besides, the maximum pollution and vitrification rates were recorded in 60 min immersion time (33\% and 37\%, respectively) (Fig. 3b). Taken together, the current study revealed that using immersion frequency less than every $8 \mathrm{~h}$ and immersion time less than $10 \mathrm{~min}$ in TIBS caused the lowest pollution and vitrification rate for $S$. sagittifolia.

\subsection{Root and Acclimatization}

Since the best rooting percentage was obtained in TIBS (Tables 1 and 2), the results indicated that immersion frequency more than every $6 \mathrm{~h}$ and immersion time more than $10 \mathrm{~min}$ produced greater root lengths and more root numbers. The optimum concentration of plant growth regulators for the best length and numbers of roots per explants was obtained in subculture medium containing $2 \mathrm{mg} / \mathrm{L} \mathrm{BA}$ and 0.5 $\mathrm{mg} / \mathrm{L}$ NAA in three method cultures (Table 3). Considering medium containing $4 \mathrm{mg} / \mathrm{L} \mathrm{BA}$ obtained the highest shoot proliferation rate in semi-solid medium (3.6), liquid medium (4.5) and TIBS (23), the subculture medium containing $4 \mathrm{mg} / \mathrm{L} \mathrm{BA}$ and 0.5 mg/L NAA in TIBS using 10 min immersion every 6 $\mathrm{h}$ was selected to be routinely used for rooting. After four weeks of culture, rooting was observed in $S$. sagittifolia (Fig. 4). The rooting generally started after four weeks culturing. At six weeks culture, $S$. sagittifolia resulted in $80 \%, 85 \%$ and $100 \%$ rooting in semi-solid medium, liquid medium and TIBS, respectively.

After $50 \mathrm{~d}$ culture of $S$. sagittifolia, the plantlets were transferred into the greenhouse (Fig. 4). Shoots in

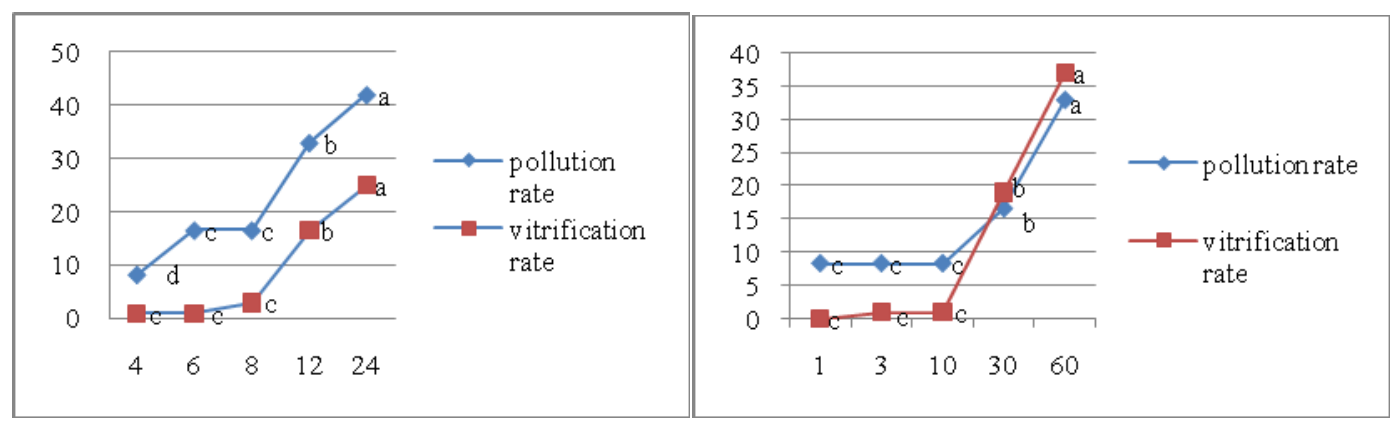

(a) Different immersion frequencies

(b) Different immersion times

Fig. 3 Effects of different immersion frequencies ( $3 \mathrm{~min}$ immersion every 4, 6, 8, 12 or $24 \mathrm{~h}$ ) and different immersion times $(1,3,10,30$ or $60 \mathrm{~min})$ on pollution and vitrification rate after five weeks in TIBS.

${ }^{\mathrm{a}-\mathrm{c}}$ Different letters indicate significant differences $(P<0.05)$ according to the post-hoc multiple comparisons test. 


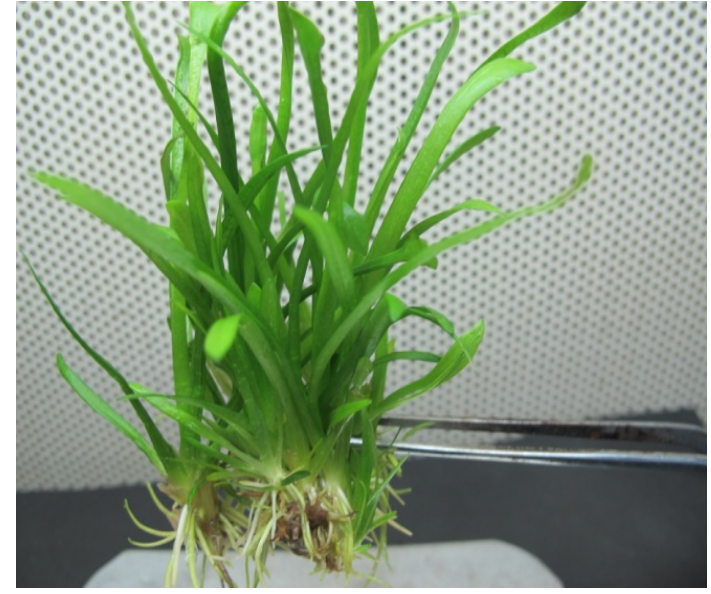

(a) Rooting in TIBS after four weeks

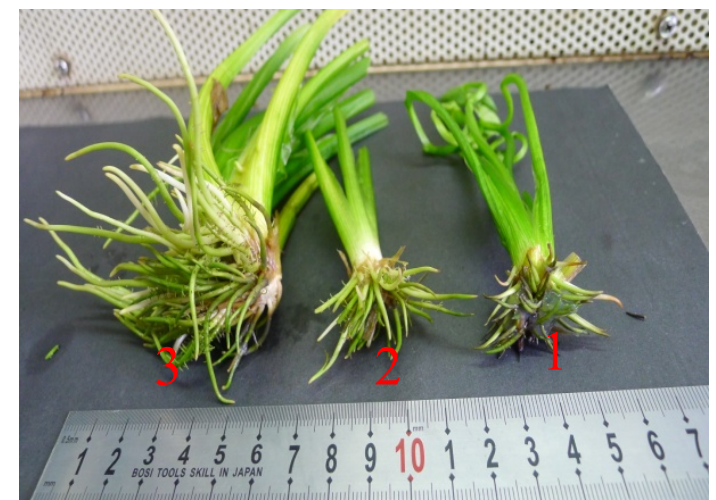

(c) The formation of root after $50 \mathrm{~d}$ in

semi-solid medium (1), liquid medium (2) and TIBS (3)

Fig. 4 Root formation of $S$. sagittifolia explants in TIBS.

in three cultured methods were subjected to $7 \mathrm{~d}$ acclimatization in the greenhouse, and then transplanted into beds in the greenhouse to observe plantlet survival and growth. Plantlets cultured in TIBS tended to resume shoot growth more quickly (6 d) compared with semi-solid medium ( $8 \mathrm{~d}$ ) and liquid medium (10 d). After one month, compared to $80 \%$ and $86 \%$ plant survival rate in conventional semi-solid and liquid culture, 94\% plant survival was obtained in the growth room (TIBS). Furthermore, the plants grew more vigourous (Fig. 4). Therefore, TIBS method for plant acclimatization was satisfactory.

\section{Discussion}

This study is an attempt to investigate the efficient and automated mass production of $S$. sagittifolia plantlets by TIBS. Different immersion frequencies

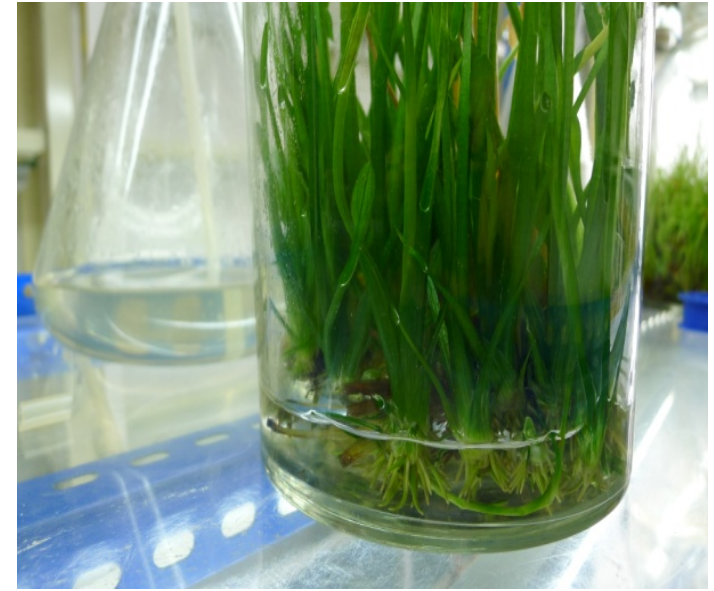

(b) Rooting in TIBS after six weeks

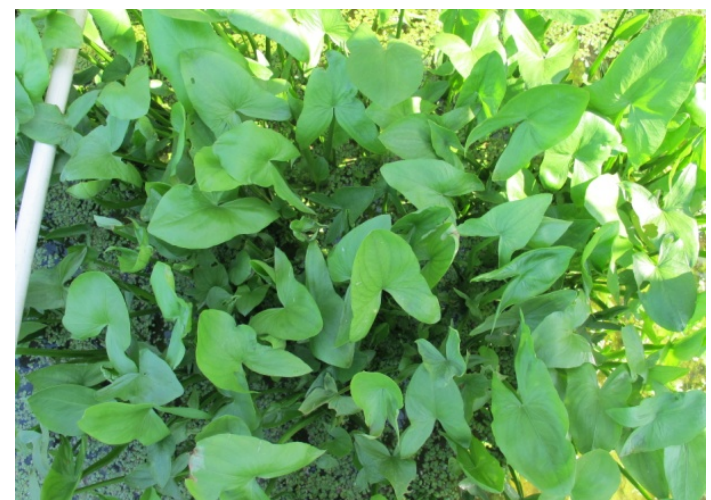

(d) After $7 \mathrm{~d}$ acclimatization, plantlets transferred to greenhouse beds and allowed to grow for one month

and immersion times were tested to verify the optimum value for shoot proliferation and growth in TIBS. The promoting growth and shoot proliferation were recorded after treatment with higher immersion frequency (every $6 \mathrm{~h}$ ) and shorter immersion times (3 min, $10 \mathrm{~min}$ ), which were better than lower immersion frequencies (every 12, 16, $24 \mathrm{~h}$ ) or longer immersion times (30 min, $60 \mathrm{~min}$ ). Under this condition, the highest proliferation rate (23.5) was achieved. This result was consistent with that of Ramos-Castella et al. [14], who obtained a maximum of $14.27 \pm 0.89$ for Vanilla planifolia shoots per explants with $2 \mathrm{~min}$ immersions every $4 \mathrm{~h}$ for the micropropagation by a TIBS. Gatica-Arias and Weber [15] reported the similar results for organogenic calli that high immersion frequency (every $6 \mathrm{~h}$ ) induced shoot and promoted hop micropropagation. In contrast to the 
results in this paper, Sreedhar [16] found that longer immersion times $(30 \mathrm{~min}$ ) every $8 \mathrm{~h}$ obtained a maximum of 2.42 vanilla shoots per explants using the Growtek $^{\mathrm{TM}}$ system. Valdez-Tapia et al. [17] reported that low immersion frequency (every $24 \mathrm{~h}$ ) produced better results than higher frequencies (every $3 \mathrm{~h}$ and $12 \mathrm{~h})$ for Castilleja tenuiflora. Therefore, the results are consistent with Berthouly and Etienne [7], who reported that the optimum immersion frequencies differed among explants types and species. The results in this study also showed that longer immersion time (from $1 \mathrm{~min}$ to $30 \mathrm{~min}$ every $6 \mathrm{~h}$ ) and lower immersion frequency (from $4 \mathrm{~h}$ to $24 \mathrm{~h}$ ) were beneficial to the number of leaves and roots and stem diameter, but no effect on shoot proliferation. It indicates that $S$. sagittifolia is a nutrient-demanding species. Gao et al. [18] reported the similar results for water chestnut with lower frequencies producing better rooting.

Furthermore, vitrification and shoot pollution rate increased in the plantlets with longer immersion time (30 $\mathrm{min}, 60 \mathrm{~min}$ ) and lower immersion frequency (12 h, 24 h) (Figs. 3a and 3b). The results from this study showed that $30 \mathrm{~min}$ immersion every $12 \mathrm{~h}$ and $60 \mathrm{~min}$ immersion every $24 \mathrm{~h}$ induced vitrification and pollution rate in shoot tips $16.6 \%$ and $19 \%, 33 \%$ and $37 \%$, respectively. There are distinct decreases in pollution rate $(8.3 \%)$ in TIBS (10 min every $6 \mathrm{~h}$ ) compared with that (more than 50\%) in conventional semi-solid and liquid culture, which may due to that TIBS causing gentle ventilation of the air in the bioreactor allows medium components sufficient and the sequential medium changing [19-21]. However, changing immersion frequencies from every $4 \mathrm{~h}$ to $8 \mathrm{~h}$, vitrification did not occur. The same trend was observed by Valdz-Tapia et al. [17], who found that those with the longest total daily immersion times (60 min every $24 \mathrm{~h}$ ) resulted in the production of vitrification in Castilleja tenuiflora. In this study, it was indicated that longer immersion times induce vitrification, and also found that lower immersion frequency may prevent vitrification, but result in the production of vigorous plants. This results were consistent with the Ramos-Castella study on Vanilla plansifolia Jacks ex Andrews [14]. On the other hand, Albarran et al. [19] reported that no relation between hyperhudricity of Coffea arabica somatic embryos in different immersion intervals. Martre et al. [22] also found that the water content of Hevea brasiliensis embryogenic callus was stable among different cycles of immersion in temporary immersion system. This may be due to explants types and different optimum conditions. However, these possibilities required further study.

In the present study, TIBS allowed a significantly higher shoot proliferation rate (23) and better growth parameter (leaves and roots number, stem diameter, root and shoot length) compared with that observed in conventional semi-solid (3.6) and liquid culture (4.5). The reason for these results may due to TIBS with temporary immersions uptake of medium ingredients and plant growth regulators over the whole plant surface, especially leaves, can improve the growth of plantlets [23, 24]; and medium components were transferred to growing regions with shorter distance. High cytokinin concentrations can promote vitrification [25]. Similarly, medium containing 4 $\mathrm{mg} / \mathrm{L}$ BA can induce the vitrified shoots in conventional semi-solid and liquid medium. However, vitrification not occurred in TIBS using immersion time less than $10 \mathrm{~min}$, irrespective of immersion frequencies. The reason for this seems due to rapid diffusion of nutrient in liquid medium, and the whole plant can efficiently absorb medium components directly, especially leaves. One interesting result was that NAA content less $(0.1 \mathrm{mg} / \mathrm{L})$ or more $(0.5 \mathrm{mg} / \mathrm{L})$ does not affect the number of leaves in TIBS, which may due to the volume of the container were enough or treat conditions satisfied. TIBS also can be used for root formation with subculture medium containing 4 $\mathrm{mg} / \mathrm{L} \quad \mathrm{BA}$ and $0.5 \mathrm{mg} / \mathrm{L}$ NAA, using $10 \mathrm{~min}$ immersion every $6 \mathrm{~h}$. Without additional rooting medium and culture, the results showed high shoot 
proliferation, $100 \%$ rooting and $94 \%$ plant survival, which indicated that TIBS is encouraging in development of $S$. sagittifolia.

\section{Conclusions}

In conclusion, this is the first report to define the culture conditions for shoot proliferation and growth by application of TIBS in S. sagittifolia. Through comparison of shoot proliferation and growth parameters (number of leaves and roots, root and shoot length, stem diameter per explants) in TIBS with those in conventional semi-solid and liquid medium, it indicates that TIBS is more efficient method for higher proliferation rate and better growth parameter. TIBS-cultured plants also exhibited well-developed root and high survival rates. Therefore, temporary immersion bioreactors are appealing for scientists, and for commercial production for their automation which reduces costs and labor.

\section{Acknowledgments}

Financial assistance was provided by the Features Research Station on S. sagittifolia in Guangxi autonomous region, China, which was co-built by province's Agriculture Department and Biotechnology Research Institute. Gratitude was expressed to suggestion and help given by associate professor Shaolong Wei, research assistant Kunpeng Ou, senior agronomies Zhihuan Mo and Chi Zhang, professor Lijuan Chen, Ph.D. Cong Luo and professor Xinhua $\mathrm{He}$, as well as to Zhicheng Lin and Fanglian He for performing this work.

\section{References}

[1] Wang, L. P., Yan, S. C., Yan, J., and Wu, H. 2011. "Investigation and Collection of the Aquatic Vegetables Germplasm Resources in Yunnan Province." Modern Chinese Medicine Research and Practice 21 (2): 25-8. (in Chinese)

[2] Quiala, E., Canal, M. J., Meijón, M., Rpdríguez, R., Chávez, M., Valledor, L., De Feria, M., and Barbón, R. 2012. "Morphological and Physiological Responses of Proliferating Shoots of Teak to Temporary Immersion and BA Treatments." Plant Cell Tiss. Org. Cult. 109 (2): 223-34.

[3] Ziv, M. 2005. "Simple Bioreactors for Mass Propagation of Plants." In Liquid Culture Systems for in Vitro Plant Propagation, edited by Hvoslef-Eide, A. K., and Preil, W. Dordrecht: Springer, 79-93.

[4] Aitken-Christie, J. 1991. “Automation.” In Micropropagation: Technology and Application, edited by Debergh, P. C., and Zimmerman, R. H. Dordrecht: Kluwer, 342-54.

[5] Ascough, G. D., and Fennel, C. W. 2004. "The Regeneration of Plant Growth and Development in Liquid Culture." South Afr. J. Bot. 70 (2): 181-90.

[6] Preil, W. 2005. "General Introduction: A Personal Reflection on the Use of Liquid Media for in Vitro Culture." In Liquid Culture Systems for in Vitro Plant Propagation, edited by Hvoslef-Eide, A. K., and Preil, W. Dordrecht: Springer, 1-18.

[7] Berthouly, M., and Etienne, H. 2005. "Temporary Immersion System: A New Concept for Use Liquid Medium in Mass Propagation.” In Liquid Culture Systems for in Vitro Plant Propagation, edited by Hvoslef-Eide, A. K., and Preil, W. Dordrecht: Springer, 165-96.

[8] Kevers, C., Franck, T., Strasser, R. J., Dommes, J., and Gaspar, T. 2004. "Hyperhydricity of Micropropagated Shoots: A Typically Stress-Induced Change of Physiological State.” Plant Cell Tiss. Org. Cult. 77 (2): 181-91.

[9] Zhu, H. L., Ke, W. D., and Wang, L. P. 2006. "Tissue Culture and Rapid Propagation on Sagittaria sagittifolia." Journal of China Vegetable (3): 15-7. (in Chinese)

[10] Huang, K. F., and Shi, Z. 2011. "Shoot Tip Tissue Culture on Sagittaria sagittifolia." J. Anhui Agri. Sci. 39: 8848-60. (in Chinese)

[11] Mallón, R., Covelo, P., and Vieitez, A. M. 2012. "Improving Secondary Embryogenesis in Quercus robur: Application of Temporary Immersion for Mass Propagation." Trees 26 (3): 731-41.

[12] Murashige, T., and Skoog, F. 1962. "A Revised Media for Rapid Growth and Bioassays with Tobacco Tissue Cultures." Physiologia Plantarum 15: 473-97.

[13] Niemenak, N., Noah, A. M., and Omokolo, D. N. 2013. "Micropropagation of Cocoyam (Xanthosoma sagittifolium L. Schott) in Temporary Immersion Bioreactor." Plant Biotechnol. Rep. 7 (3): 383-90.

[14] Ramos-Castellá, A., Iglesias-Andreu, L. G., Bello-Bello, J., and Lee-Espinosa, H. 2014. "Improved Propagation of Vanilla (Vanilla planifolia Jacks. ex Andrews) Using a Temporary Immersion System." In Vitro Cell. Dev. Biol. Plant 50 (5): 576-81.

[15] Gatica-Arias, A., and Weber, G. 2013. "Genetic 
Transformation of Hop (Humulus lupulus L. cv. Tettnanger) by Particle Bombardment and Plant Regeneration Using A Temporary Immersion System." In Vitro Cell. Dev. Biol. Plant 49 (6): 656-64.

[16] Sreedhar, R. V. 2009. "Novel Approaches for Molecular Analyses, Micropropagation and Curing of Vanilla (Vanilla planifolia).” Ph.D. thesis, University of Mysore, New Delhi, India.

[17] Valdez-Tapia, R., Capataz-Tafur, J., López-Laredo, A. R., Trejo-Espino, J. L., and Trejo-Tapia, G. 2014. "Effect of Immersion Cycles on Growth, Phenolics Content and Antioxidant Properties of Castilleja tenuiflora Shoots." In Vitro Cell. Dev. Biol. Plant 50 (4): 471-7.

[18] Gao, M. P., Jiang, W., Wei, S. L., Lin, Z. C., Cai, B. H., Yang, L., Luo, C., He, X. H., Tan, J., and Chen, L. J. 2015. "High Efficiency Propagation of Chinese Water Chestnut [Eleocharis dulcis (Burm. f.) Trin. ex Hensch] Using a Temporary Immersion Bioreactor System.” Plant Cell Tiss. Org. Cult. 121 (3): 761-72.

[19] Albarran, J., Bertrand, B., Lartaud, M., and Etienne, H. 2005. "Cycle Characteristics in a Temporary Immersion Bioreactor Affect Regeneration, Morphology, Water and Mineral Status of Coffee (Coffea arabica) Somatic Embryos." Plant Cell Tiss. Org. Cult. 81 (1): 27-36.

[20] Teisson, C., and Alvard, D. 1995. "A New Concept of Plant in Vitro Cultivation Liquid Medium: Temporary
Immersion.” In Current Tissues in Plant Molecular and Cellular Biology, edited by Terri, M., Cella, R., and Falavigna, A. Dordrecht: Kluwer, 105-10.

[21] Zhu, L. H., Li, X. Y., and Welander, M. 2005. "Optimization of Growing Conditions for the Apple Root Stock M26 Grown in RITA Containers Using Temporary Immersion Principle." Plant Cell Tiss. Org. Cult. 81 (3): 313-8.

[22] Martre, P., Lacan, D., Just, D., and Teisson, C. 2001. "Physiological Effects of Temporary Immersion on Hevea brasiliensis Callus." Plant Cell Tiss. Org. Cult. 67 (1): 25-35.

[23] Quiala, E., Barbon, R., Jimemez, E., De Feria, M., Chavez, M., Capote, A., and Perez, N. 2006. "Biomass Production of Cymbopogon citrates (D.C.) Stapf, a Medicinal Plant, in Temporary Immersion System." In Vitro Cell. Dev. Biol. Plant 42 (3): 298-300.

[24] De Klerk, G. J., and Ter Brugge, J. 2011. "Micropropagation of Dahlia in Static Liquid Medium Using Slow-Release Tools of Medium Ingredients." Sci. Hortic. 127 (4): 542-7.

[25] Ivanov, I., Georgiev, V., Georgiev, M., Ilieva, M., and Pavlov, A. 2011. "Galanthamine and Related Alkaloids Production by Leucojum aestivum L. Shoot Culture Using a Temporary Immersion Technology." Appl. Biochem. Biotechnol. 163 (2): 268-77. 